\title{
The Effect of Corporate Social Responsibility (CSR), Food Quality, and Perceived Value on Repurchase Intention Through Customer Sat- isfaction as Intervening Variables in The Pandemi Covid-19 Era (Study On "Chatime" Bubble Drink Products)
}

\author{
Mohc. Velian Muhajir \\ Faculty of Economics and Business, State University of Surabaya, Indonesia \\ Email: velian.17080574006@mhs.unesa.ac.id \\ Tias Andarini Indarwati \\ Faculty of Economics and Business, State University of Surabaya, Indonesia \\ Email: tiasindarwati@unesa.ac.id
}

\begin{abstract}
Bubble drink products are one of the beverage trends that have developed this year, even during the Covid 19 pandemic. One of the bubble drink brands that is in demand by the public especially teenagers in Indonesia is Chatime, in which consumers do not buy Chatime just once. The purpose of this paper is to study the effect of corporate social responsibility, food quality, customer satisfaction, on repurchase intention, through customer satisfaction. The research sampling techniques used are nonprobability sampling by judgmental sampling. This study focuses on Chatime consumers who bought Chatime products during a pandemic Covid-19. The data analysis technique is used path analysis. The results show that CSR has a negative effect on repurchase intention and customer satisfaction, food quality has a positive effect on repurchase intention and customer satisfaction, perceived value has a negative effect on repurchase intention, but has a positive effect on customer satisfaction.
\end{abstract}

Keywords: Corporate Social Responsibility, Customer Satisfaction, Food Quality;Perceived Value, Repurchase Intention

Received: 28 April 2021;

Accepted: 2 June 2021 ;

Publish: June 2021

\section{How to Cite:}

Muhajir, M.V., Indarwati, T.A. (2021). The Effect of Corporate Social Responsibility (CSR), Food Quality, and Perceived Value on Repurchase Intention Through Customer Satisfaction as Intervening Variables in The Pandemi Covid-19 Era (Study On "Chatime" Bubble Drink Products). Journal of Business and Behavioural Entrepreneurship, 5(1), 60-77. https://doi.org/10.21009/JOBBE.005.1.04 


\section{INTRODUCTION}

The culinary industry is the most resilient field in the pandemic era. Referring to data from the Badan Pusat Statistik (BPS), the contribution of the processing industry to GDP reached $19.87 \%$ in the second quarter of 2020 . The above phenomenon is due to the fact that food and drink are primary needs for humans, as well as the emergence of various trends and innovations from culinary business actors that are currently on the rise. One of the businesses in the culinary field that is currently trending is bubble drink products.

Bubble drink is a contemporary drink that is popular in various countries. This drink comes from Taiwan which is made from tapioca flour, and served with syrup, tea, and milk (detik.com, 2018). Chatime is one of the bubble drink brands that is in demand by the public, especially teenagers in Indonesia. Chatime was able to stay in the first place in the Top brand index for three consecutive years, from 2018 to 2020. This shows that the Chatime brand has good mind share, market share, and commitment share according to consumers. This measurement is in accordance with the criteria used to measure a brand to occupy a position in the top brand index by considering these three things (Top Brand Award, 2019).

Chatime created a movement with the theme "Chatime Berbagi" which was carried out during a pandemic. This activity is a CSR program by distributing more than 100 thousand glasses of Chatime products to medical personnel on duty at the Covid19 referral hospital in the City of Jakarta. This activity continues by targeting hospitals and health centers in 10 other areas in Indonesia, including Surabaya, Medan, Batam, Semarang, Yogyakarta, Bali, Balikpapan, Banjarmasin, Makassar and Manado (timesindonesia.co.id, 2020). The Chatime sharing program also involves consumers where consumers can use Chatime product sharing services to online motorcycle taxi drivers when purchasing Chatime products (Harianbirawa.co.id, 2020). In this study, the CSR variable is derived from external factors that influence consumer behavior. Research conducted by Thi \& Le Van, (2016) states that companies in the consumer industry must develop marketing based on a social responsibility component to strengthen trademarks in consumer perceptions, and change consumers' thoughts into purchasing interests. In addition to examining the CSR variable, this study also measures consumer satisfaction and repurchase intentions based on the food quality of Chatime products.

The food quality variable in this study is derived from the internal factors of consumer behavior, namely from the management of information and perceptions that also play an important role in encouraging consumer satisfaction, as well as consumer repurchase intentions. Kotler \& Armstrong (2012: 142) said that product quality is the ability of a product, both goods and services, to show its function. The results of research conducted by Muliawan \& M, (2018) state that companies must be able to improve and maintain the quality of their products based on the various dimensions in them to be able to increase consumer repurchase intentions. This study not only uses the CSR variable and food quality to measure consumer satisfaction and repurchase intention, but a further and in-depth study using the variable perceived value.

Perceived value is the next thing which is also derived from information management and perception factors, which are also a driving factor for consumer satisfaction and consumer repurchase intentions. According to Pham et al., (2018) perceived value is a comparison between what consumers issue and what consumers can feel from the products they have purchased. Chatime is considered capable of providing excellent quality to consumers both in terms of service and in terms of products, be-

The Effect of Corporate Social Responsibility (CSR), Food Quality, and Perceived Value on Repurchase Intention Through Customer Satisfaction as Intervening Variables in The Pandemi Covid-19 Era (Study 
sides that Chatime is also able to provide added value to consumers which is a separate reason for consumers to make repeat purchases.

This study aims to determine the direct effect of CSR, food quality, and perceived value on customer satisfaction and repurchase intention, as well as the direct effect of customer satisfaction on repurchase intention. Therefore, it is hoped that this research will be able to make an important contribution to Chatime in developing its products and services, in order to be able to make consumers satisfied and have the intention to make repeat purchases.

\section{LITERATURE REVIEW}

\section{Repurchase Intention}

Repeat purchase is a condition in which consumers are willing to repurchase products from certain brands after use (Chiang 2016) in (Ling-Chuan Huang, et al, 2019). This opinion is also supported by Erkan \& Evans (2016) which states that repurchase intention is considered as the customer's intention to repurchase a product from a certain brand, namely the customer's psychological commitment to service. The indicators used in this study refer to Chiang's (2016) research in Ling-Chuan Huang ,. et al (2019) for measuring the repurchase intention variable that has been adjusted to the research needs, namely there are 2 indicators, namely repeated purchase, and willingness to recommend.

\section{Corporate Social Responsibility (CSR)}

CSR is a commitment to improving people's welfare through discretionary business practices and the contribution of company resources (Kotler \& Lee, 2005) in (Chung et al., 2015). This study defines CSR as programs, activities, processes, and perceived social obligations that are made as a form of business commitment to contribute to sustainable economic development, improve people's welfare, and improve the quality of life of the community by using company-owned resources (Wood, 1991; Sen and Bhattacharya, 2001) in (Nareeman \& Hassan, 2013). There is 1 indicator used to measure the CSR variable in this study by referring to the research of Thi \& Le Van, (2016), and Chung et al., (2015) which has been adjusted to the needs of this study, namely philanthropic responsibility.

\section{Food Quality}

Food quality refers to the overall performance of the food itself to meet consumer needs and is considered an important element of the customer experience with a restaurant that offers such food (Ha \& Jang, 2010) on (Dwi Suhartanto, et al, 2019). Food quality which in this study is used to measure the quality of drinks is an important element of the customer experience of the products consumed, and quality drinks are drinks that are able to meet all consumer needs for these drinks (Ha \& Jang, 2010) on (Dwi Suhartanto, Et al., 2019). There are 2 indicators used to measure the food quality variable and it has been adjusted to the needs of this study, which refers to the opinion of West, Wood and Harger (2006, p. 39), Gaman and Sherrington (1996, p.132) and Jones (2000, p. .109-110) in (Margaretha Fiani S. and Edwin Japarianto, SE, 2012). 


\section{Perceived Value}

Perceived Value is an overall consumer assessment of the function or usefulness of a product based on perceptions of what is received with what is given (Zeithaml, 1988) in (Nguyen Xuan Nhi, 2019). In this study, perceived value is defined as the difference that consumers perceive between what is sacrificed and what is obtained in the product they buy (Zeitham, 1988) in (Xuan Phuc Tran, et al, 2019). The indicator used to measure the perceived value variable refers to research conducted by Konuk (2018) and Kuo et al., (2009), and it has been adjusted to this study that there are 2 indicators, namely the price of this product is economical, and the product and service is a good buy.

\section{Customer Satisfaction}

Customer satisfaction is an emotional response felt by consumers on the evaluation of a product that is consumed (Tjiptono, 2012: 301). There are 5 factors that influence consumer satisfaction according to Lupiyoadi (2001: 122), among others, product quality, service quality, emotion, price, cost. Every company will definitely use the measurement of customer satisfaction with the products they offer, this aims to evaluate product performance and to find out future product development plans. The indicator used to measure the customer satisfaction variable in this study refers to the research of Ha \& Jang (2010), which is that there are 3 indicators.

\section{The Effect of Corporate Social Responsibility (X1) on Repurchase Intention (Y)}

The results of research by Thi \& Le Van, (2016) state that CSR (economic responsibility, legal responsibility, philanthropic responsibility, environmental responsibility) has a positive and significant effect on repurchase intention. The study explains that companies in the consumer industry must develop marketing based on a social responsibility component to strengthen trademarks in consumer perceptions, and change consumers' thoughts into purchasing interests. Customers tend to increase interest in repeat purchases at companies that are considered responsible to society. Another study that states the same thing is a study conducted by Saju Jose Nilesh Khare F. Robert Buchanan, (2015), this study explains that the perceptions presented by CSR activities can reduce the negative effects of consumer dissatisfaction on their next purchase. Another study that states the same thing is by Tsai et al., (2016) which states that CSR (CSR to Employee, CSR to Customer) has an effect on repurchase intention. The results of this study identify that there are 3 CSR issues that are very important to customers, namely compliance with consumer rights, compliance with laws and regulations, and provision of accurate information. This study is also corroborated by the results of research by Bello et al., (2020).

\section{The Effect of Food Quality (X2) on Repurchase Intention (Y)}

Research conducted by Muliawan \& M, (2018) states that food quality has an influence on repurchase intention. The company has been able to improve and maintain the quality of its products based on various dimensions in it. The relationship between food quality and repurchase intention can also be proven to have a significant

The Effect of Corporate Social Responsibility (CSR), Food Quality, and Perceived Value on Repurchase Intention Through Customer Satisfaction as Intervening Variables in The Pandemi Covid-19 Era (Study 
relationship. Research that states the same thing is by Faradiba \& Astuti, (2013), Hermanto \& Cahyadi, (2015), and Harfania, (2018), which states that there is a positive and significant effect on product quality (food) on repurchase intention.

A different opinion is conveyed by Bahar \& Sjahruddin, (2017) which states that food quality has no effect on repurchase intention. This study explains that the product of the object of research has low durability, this is due to several factors, one of which is the product packaging which cannot maintain the maximum durability of the product. This causes consumer perceptions of product quality to decline, so that in this study the results show that product quality has no effect on repurchase interest.

\section{The Effect of Perceived Value (X3) on Impulse Buying Behavior (Y)}

Research by Pham et al., (2018) states that perceived value has a positive and significant effect on repurchase intention. The research explains that perceived value is a comparison between what consumers spend and what consumers can feel from the products they have purchased. Companies are required to be able to increase convenience and reduce non-monetary costs incurred by consumers such as time and energy which aim to increase the perceived value of customers, which if the perceived value increases, the intention of consumers to make repeat purchases will also increase. A similar opinion was also conveyed by Tresna et al., (2019) in their research stating that perceived value has an influence on repurchase intention. The study also explained that the variable perceived value also included functional, social and emotional values in it. This opinion also supports other research conducted by Huang et al., (2019), Nhi et al., (2019), and Frendy (2013).

\section{The Effect of Corporate Social Responsibility (X1) on Customer Satisfaction (Z)}

The results of research by Loureiro et al., (2012) show that the perception of CSR according to buyers will affect their satisfaction with these products, but not all CSR problems have a big impact on consumer satisfaction, there are several types of CSR that have a big impact on consumer satisfaction, namely CSR. in the environmental field. A similar opinion was stated by Chung et al., (2015) that CSR affects Customer Satisfaction. This study explains that CSR to customer which aims to protect customers is more important than CSR to the contribution to the environment. The results of the above research are also supported by research conducted by Nareeman \& Hassan, (2013). Another study that states the same thing is research conducted by Pérez \& del Bosque, (2015).

\section{The Effect of Food Quality (X2) on Customer Satisfaction (Z)}

Research by Hidayat et al., (2020) states that there is a positive effect of food quality on customer satisfaction. In this study, it is explained that company management must be able to provide innovation in the variants of beverage products offered, maintain and control the temperature of the food when it is served, and increase the portion size of the food served. This is an effort made to maintain consumer satisfaction with food quality. A similar opinion is also expressed by Berliansyah \& Suroso (2018), and Ha \& Jang (2010), that there is a significant relationship and influence between food quality and customer satisfaction. Other studies that state the same thing are research conducted by Weliani (2017) and research conducted by Muliawan \& M 
(2018) which states that there is a positive and significant effect of food quality on customer satisfaction.

Another opinion was conveyed by Nancy et al., (2020) stating that Food Quality has no effect on Customer Satisfaction. Consumers of restaurants with open kitchens feel satisfaction not from the quality of the food served but from other factors that cannot be explained explicitly in this study because they are not examined more deeply on this matter. The researcher also explained that in this study there were no restrictions on the objects used, so that the respondent is anyone who has ever visited an open kitchen restaurant with any brand, so there is a possibility that the respondent has visited an open kitchen restaurant that offers food quality that does not match the respondent's expectations. resulting in food quality being seen as a variable that has no effect on customer satisfaction.

\section{The Effect of Perceived Value (X3) on Customer Satisfaction (Z)}

Leonnard (2018) states that there is a positive and significant effect of perceived value on customer satisfaction. A similar opinion was conveyed by Abdul Raji \& Mohd Nazri et al., (2016) which stated that there are 3 sub-hypothesis of perceived value used, namely emotional responses, behavioral price, and reputation, all of which state a positive and significant relationship to customer satisfaction. The opinion above is also corroborated by the opinion of research conducted by Frendy (2013) which states the same thing.

\section{The Effect of Customer Satisfaction (Z) on Repurchase Intention (Y)}

Research by Berliansyah \& Suroso, (2018) states that to increase consumer repurchase intention, upper-level management must pay attention to consumer satisfaction, this can be realized by improving the quality of food and beverages, and considering the appropriate price for the products offered. A similar opinion was conveyed by Hidayat et al., (2020) which in order to increase repurchase intention, businesses must prioritize consumer satisfaction above all else. Other studies that support the above statement include research conducted by Weliani (2017), Leonnard (2018), Frendy (2013).

A different opinion was conveyed by Vigripat \& Chan (2007) which stated that there was no effect of customer satisfaction on repurchase intention. In this study, it is explained that consumers who are satisfied with previously purchased car products have a small or even impossible possibility to repurchase a car with the same brand or type. The study also revealed that satisfied consumers are more likely to repurchase fancier products if they have enough money.

\section{Hypothesis}

H1 : Corporate Social Responsibility has a significant effect on Repurchase Intention.

H2 : Food Quality has a significant effect on Repurchase Intention.

H3 : Perceived Value has a significant effect on Repur chase Intention.

H4 : Corporate Social Responsibility has a significant effect on Customer Satisfaction.

H5 : Food Quality has a significant effect on Customer Satisfaction.

H6 : Perceived Value has a significant effect on Customer Satisfaction.

The Effect of Corporate Social Responsibility (CSR), Food Quality, and Perceived Value on Repurchase Intention Through Customer Satisfaction as Intervening Variables in The Pandemi Covid-19 Era (Study 
H7 : Customer Satisfaction has a significant effect on Repurchase Intention.

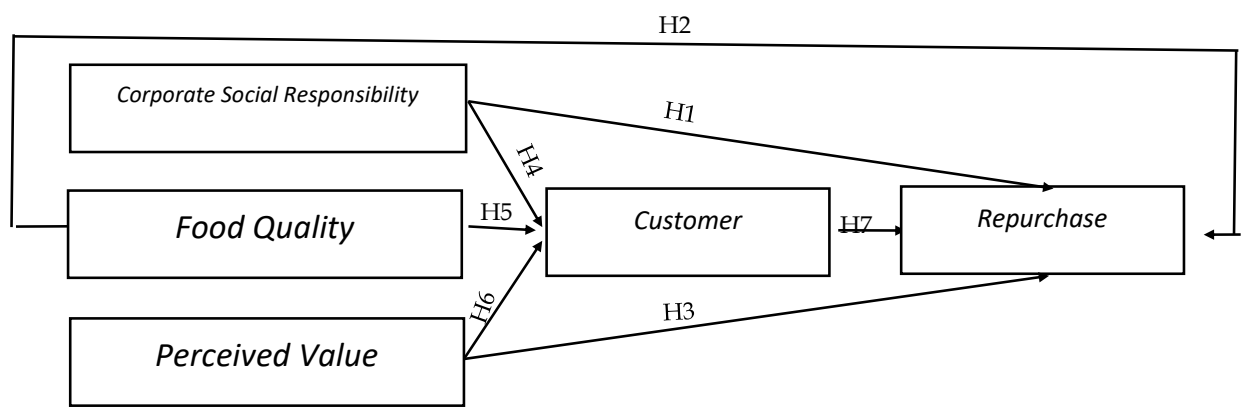

Figure 1. CONCEPTUAL FRAMEWORK

Source: Data processed (2021)

\section{RESEARCH METHODS}

This research belongs to the type of quantitative research. The population used is an unknown number of Chatime consumers (Infinnite), with the characteristics of having bought Chatime products since November 2020, knowing Chatime's CSR program, namely the "Chatime Berbagi" program, and with an age range of 15-50 years. The sampling technique used in this study is non-probability sampling by relying on the judgment or personal judgment of the researcher. The number of respondents in this study was 200 respondents. The research was conducted by distributing questionnaires online to respondents according to the characteristics that had been determined by measuring using the Likert scale. The data analysis technique uses Path Analysis using the IBM SPSS AMOS (Analysis of Moment Structure) version 24 application.

An explanation of the statement items used to measure the CSR variable, food quality, perceived value, repurchase intention, and customer satisfaction that have been adjusted to the research needs is as shown in table 1 below

The Effect of Corporate Social Responsibility (CSR), Food Quality, and Perceived Value on Repurchase Intention Through Customer Satisfaction as Intervening Variables in The Pandemi Covid-19 Era (Study On "Chatime" Bubble Drink Products). 


\section{Table 1}

\section{MEASUREMENT OF RESEARCH VARIABLES}

\begin{tabular}{|c|c|c|}
\hline Variabel & Indikator & Item Pernyataan \\
\hline \multirow{2}{*}{$\begin{array}{l}\text { Corporate } \\
\text { Social Respon- } \\
\text { sibility (X1) }\end{array}$} & \multirow{2}{*}{$\begin{array}{l}\text { Phylantropic } \\
\text { Responsibility } \\
\quad(\mathrm{X} 1.1)\end{array}$} & $\begin{array}{l}\text { Chatime shows its concern for medical personnel by } \\
\text { distributing its products for free during the pandemic era } \\
\text { (X1.1.1) }\end{array}$ \\
\hline & & $\begin{array}{l}\text { Chatime is able to invite the public to share with online } \\
\text { motorcycle taxi drivers }(\text { X1.1.2) }\end{array}$ \\
\hline \multirow{4}{*}{$\begin{array}{l}\text { Food Quality } \\
\qquad(\mathrm{X} 2)\end{array}$} & \multirow[b]{2}{*}{ Color $(\mathrm{X} 2.1)$} & $\begin{array}{l}\text { The variant of the Chatime drink has an interesting color } \\
\text { combination }(\mathrm{X2.1.1)}\end{array}$ \\
\hline & & $\begin{array}{l}\text { The color combination of the drinks that Chatime offers } \\
\text { is able to make me more appetizing to consume these } \\
\text { products }(\mathrm{X2.1.2)}\end{array}$ \\
\hline & \multirow{2}{*}{ Taste (X2.2) } & $\begin{array}{l}\text { The taste of the drink is the main thing that affects the } \\
\text { quality of the drink } \\
\text { (X2.2.1) }\end{array}$ \\
\hline & & $\begin{array}{l}\text { Each drink variant in Chatime products has a fresh taste } \\
(\mathrm{X} 2.2 .2)\end{array}$ \\
\hline \multirow[t]{2}{*}{$\begin{array}{l}\text { Perceived Val- } \\
\quad \text { ue (X3) }\end{array}$} & $\begin{array}{l}\text { The price of this } \\
\text { product is eco- } \\
\text { nomical }(\mathrm{X} 3.1)\end{array}$ & $\begin{array}{l}\text { The Chatime products and services that I received match } \\
\text { the sacrifices (Time, Energy, Price) that I spent }(\mathrm{X} 3.1 .1)\end{array}$ \\
\hline & $\begin{array}{l}\text { The product and } \\
\text { service is a good } \\
\quad \text { buy }(X 3.2)\end{array}$ & $\begin{array}{l}\text { The products and services provided by Chatime are } \\
\text { worth buying even during the Covid-19 pandemic } \\
(\mathrm{X} 3.2 .1)\end{array}$ \\
\hline \multirow{3}{*}{$\begin{array}{l}\text { Customer Sat- } \\
\text { isfaction }(\mathrm{Z})\end{array}$} & Happiness (Z.1) & $\begin{array}{l}\text { I had a wonderful experience while consuming chatime } \\
\text { products }(\text { Z.1.1) }\end{array}$ \\
\hline & $\begin{array}{l}\text { Contentedness } \\
(Z .2)\end{array}$ & $\begin{array}{l}\text { I feel that consuming Chatime bubble drink products can } \\
\text { meet my needs }{ }_{(Z .2 .1)}\end{array}$ \\
\hline & $\begin{array}{l}\text { Overall Satis- } \\
\text { faction }(Z .3)\end{array}$ & $\begin{array}{l}\text { Overall, I am always satisfied with Chatime's bubble } \\
\text { drink products and services even during the Covid-19 } \\
\text { pandemic }{ }_{(\mathrm{Z} .31)}\end{array}$ \\
\hline \multirow[t]{2}{*}{$\begin{array}{c}\text { Repurchase } \\
\text { Intention }(Y)\end{array}$} & $\begin{array}{l}\text { Repeated pur- } \\
\text { chase (Y.1) }\end{array}$ & I plan to repurchase Chatime products in the future ${ }_{(Y .1 .1)}$ \\
\hline & $\begin{array}{l}\text { Willingness to } \\
\text { recommend } \\
\text { (Y.2) }\end{array}$ & $\begin{array}{l}\text { I will happily recommend Chatime products to my fami- } \\
\text { ly and friends (Y.2.1) }\end{array}$ \\
\hline
\end{tabular}

Source: Data processed (2021)

\section{RESULTS AND DISCUSSION}

\section{Respondent Characteristics}

Demographic characteristics based on the age of the respondents can be seen that most respondents are in the $21-25$ years age range as many as $87(43 \%)$, and the least respondents are those with the age range 46-50 years with a total of $2(1 \%)$ respondents. Demographic characteristics based on gender, there are $149(74 \%)$ female respondents, and $51(25 \%)$ male respondents. Characteristics of respondents when viewed from the characteristics of the work there are, $131(65 \%)$ are students, $7(3 \%)$ have jobs as civil servants, $34(17 \%)$ of respondents are private employees, then 14 respondents $(7 \%)$ work as entrepreneurs, followed by respondents with a profession as housewives as many as $9(4 \%)$ of respondents, and $5(2 \%)$ of respondents with other professions, among others, as social media influencers, and several others were job

The Effect of Corporate Social Responsibility (CSR), Food Quality, and Perceived Value on Repurchase Intention Through Customer Satisfaction as Intervening Variables in The Pandemi Covid-19 Era (Study On "Chatime" Bubble Drink Products). 
seekers or in the stage of looking for work. Demographic characteristics when viewed from monthly expenditure there are $88(44 \%)$ respondents with expenses $<\mathrm{Rp}$. $1,000,000$, the next respondents with expenses of Rp. 1,000,001-Rp. 1,500,000 are 42 $(21 \%)$ respondents. The characteristics of respondents based on the location of buying Chatime in this study were dominated by respondents who bought at outlets in East Java province, namely $125(60 \%)$ respondents, followed by respondents who made purchases in West Java Province as many as $28(13 \%)$, followed by DKI Province. Jakarta as many as $21(10 \%)$, followed by respondents who bought in Central Java Province as many as $10(3 \%)$ respondents.

\section{Pre Analysis Pre-Requirement Test Results}

Before conducting the path analysis test, the researcher first conducted a prerequisite analysis test, the results of the pre-requisite analysis test can be seen in table 2 below.

\section{Table 2}

ANALYSIS PRE-REQUIREMENT TEST RESULTS

\begin{tabular}{|c|c|c|c|}
\hline No & $\begin{array}{c}\text { Pre Requirement } \\
\text { Test }\end{array}$ & Result & Information \\
\hline 1 & Normality test & $\begin{array}{l}\text { The critical ratio of the skewness value of } \\
\text { each variable shows a normal distribution } \\
\text { because it is in the range of }-2.58 \text { to } 2.58 \text { (- } \\
1,070,-2,191,1,607,-1,586,-2,233) \text {. }\end{array}$ & $\begin{array}{l}\text { The assumption of } \\
\text { multivariate normality } \\
\text { has been fulfilled and the } \\
\text { data is suitable for use in } \\
\text { the next stage. }\end{array}$ \\
\hline 2 & Linearity Test & $\begin{array}{l}\text { The significance probability value of all } \\
\text { independent variables on the dependent } \\
\text { and intervening variables is } 0,000 \text {. Signifi- } \\
\text { cance probability values that meet the cri- } \\
\text { teria are those that have a value range of } \\
0.000<0.05 \text {. }\end{array}$ & $\begin{array}{l}\text { The terms of the } \\
\text { relationship between } \\
\text { variables have met the } \\
\text { requirements and are } \\
\text { linear. }\end{array}$ \\
\hline 3 & Outlier Test & $\begin{array}{l}\text { Mahalanobis distance value is less than } \\
48.278 \text { or there is no mahalanobis d-square } \\
\text { data that exceeds } 48.278 \text {. The p } 2 \text { value, } \\
\text { does not indicate a value less than } 0.05 \text {. }\end{array}$ & $\begin{array}{l}\text { The data meet the } \\
\text { outliers test assumptions } \\
\text { and the data is suitable } \\
\text { for use in the next } \\
\text { estimation. }\end{array}$ \\
\hline 4 & $\begin{array}{c}\text { Multicolinearity } \\
\text { Test }\end{array}$ & $\begin{array}{l}\text { The determinant covariance matrix is } \\
46.659 \text {, which means that the determinant } \\
\text { covariance matrix value is far from } 0 \text {. }\end{array}$ & $\begin{array}{l}\text { in this study there was no } \\
\text { multicollinearity } \\
\text { relationship. }\end{array}$ \\
\hline
\end{tabular}

Source: Data processed (2021)

\section{Path Analysis Results}

The structural model equation (1) (2) below will show the results of the path analysis, and can be illustrated in Figure 2 below 


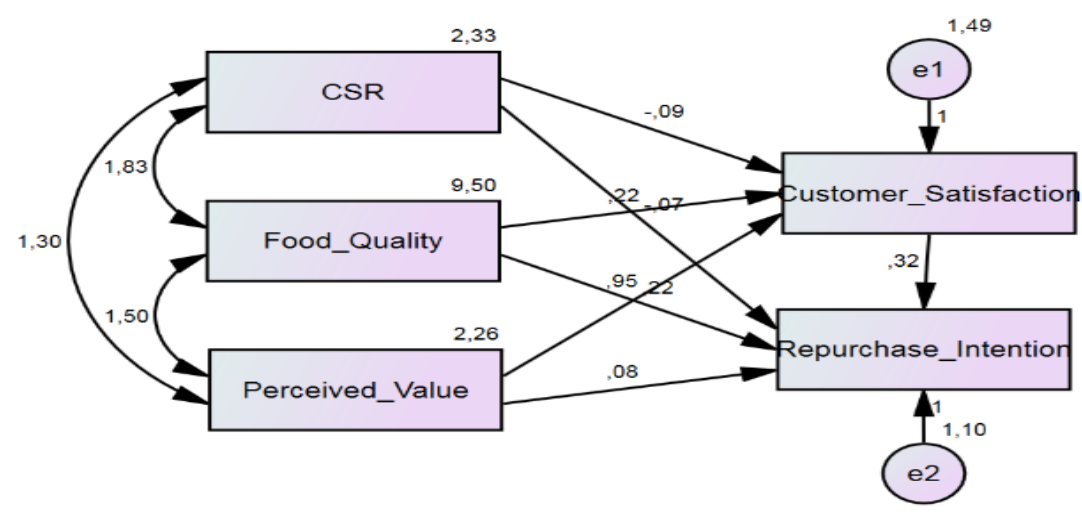

Figure 2. PATH ANALYSIS RESULTS

Source: Data processed (2021)

$$
\begin{aligned}
\mathbf{Z}= & \mathrm{b} 1 \mathrm{X} 1+\mathrm{b} 2 \mathrm{X} 2+\mathrm{b} 3 \mathrm{X} 3+\mathrm{e} 1 \\
& =0,07 \mathrm{X} 1+0,95 \mathrm{X} 2+0,08 \mathrm{X} 3+0,588 . \\
\mathbf{Y}= & \mathrm{b} 4 \mathrm{X} 1+\mathrm{b} 5 \mathrm{X} 2+\mathrm{b} 6 \mathrm{X} 3+\mathrm{b} 7 \mathrm{Z}+\mathrm{e} 2 \\
& =-0,09 \mathrm{X} 1+0,22+0,22+0,32+0,658
\end{aligned}
$$

\begin{tabular}{|c|c|c|c|c|c|}
\hline $\begin{array}{l}\text { Hipotesi } \\
\text { s }\end{array}$ & Variabel & Estimate & C.R. & $\mathbf{P}$ & Result \\
\hline H1 & Repurchase Intention $<--C S R$ & $-0,68$ & $1.15 \overline{2}^{-}$ & 0,249 & Not Supported \\
\hline $\mathrm{H} 2$ & $\begin{array}{c}\text { Repurchase Intention <-- Food } \\
\text { Quality }\end{array}$ & 0,424 & 7,431 & 0,000 & Supported \\
\hline H3 & $\begin{array}{c}\text { Repurchase Intention }<- \text { Perceived } \\
\text { Value }\end{array}$ & 0,078 & 0,992 & 0,321 & Not Supported \\
\hline $\mathrm{H} 4$ & Customer Satisfaction <-- CSR & $-0,067$ & 1,273 & 0,203 & Not Supported \\
\hline H5 & $\begin{array}{c}\text { Customer Satisfaction }<-- \text { Food } \\
\text { Quality }\end{array}$ & 0,321 & 7,019 & 0,000 & Supported \\
\hline H6 & $\begin{array}{c}\text { Customer Satisfaction <-- Per- } \\
\text { ceived Value }\end{array}$ & 0,687 & $\begin{array}{r}13,45 \\
6\end{array}$ & 0,000 & Supported \\
\hline H7 & $\begin{array}{c}\text { Repurchase Intention <-- Customer } \\
\text { Satisfaction }\end{array}$ & 0,418 & 5,270 & 0,000 & Supported \\
\hline
\end{tabular}

\section{Hypothesis Test Results}

Table 3

HYPOTHESIS TEST RESULTS

Source: Data processed (2021)

Based on table 3, the results of the $\mathrm{H} 1$ hypothesis test obtained a significance probability value of $0.249(\mathrm{p}>0.05)$ so it can be said to be insignificant or there is no effect. This means that corporate social responsibility has no effect on repurchase intention. This means that the first hypothesis (H1) is rejected. H2 hypothesis test results obtained a significance probability value of $0.000(\mathrm{P}<0.005)$. This means that food quality has a positive and significant effect on repurchase intention. This means that the second hypothesis (H2) is accepted. The results of hypothesis testing $\mathrm{H} 3$ obtained a

The Effect of Corporate Social Responsibility (CSR), Food Quality, and Perceived Value on Repurchase Intention Through Customer Satisfaction as Intervening Variables in The Pandemi Covid-19 Era (Study On "Chatime" Bubble Drink Products). 
significance probability value of $0.321(\mathrm{P}>0.005)$ so it can be said that it is not significant or has no effect. This means that perceived value has no effect on repurchase intention. This means that the third hypothesis (H3) is rejected. The results of hypothesis testing H4 obtained a significance probability value of $0.203(\mathrm{P}>0.005)$ so it can be said that it is not significant or has no effect. This means that corporate social responsibility has no effect on customer satisfaction. This means that the fourth hypothesis (H4) is rejected. The results of hypothesis testing $\mathrm{H} 5$ obtained a significance probability value of $0.000(\mathrm{P}<0.005)$. This means that food quality has a positive and significant effect on customer satisfaction. This means that the fifth hypothesis (H5) is accepted. The results of hypothesis testing $\mathrm{H} 6$ obtained a significance probability value of $0.000(\mathrm{P}<0.005)$. This means that perceived value has a positive and significant effect on repurchase intention. This means that the sixth hypothesis (H6) is accepted. The results of hypothesis testing $\mathrm{H} 7$ obtained a significance probability value of 0.000 $(\mathrm{P}<0.005)$. This means that customer satisfaction has a positive and significant effect on repurchase intention. This means that the seventh hypothesis (H7) is accepted.

\section{Sobel Test Results}

Based on the results of the sobel test in this study, it is known that the mediating variable, namely customer satisfaction, is not proven to mediate the relationship between the CSR variable and the repurchase intention variable with the CSR variable probability value of 0.21294723 ( $p>0.05$ ). Different results are shown in the relationship between the food quality variable on repurchase intention which is proven to be mediated by the intervening variable, namely customer satisfaction with a probability value of the food quality variable of $0.00002581(\mathrm{p}<0.05)$. Customer satisfaction $(Z)$ is also proven to be able to mediate the relationship between the perceived value variable on repurchase intention and the probability value of the perceived value variable of $0.00000087(\mathrm{p}<0.05)$.

\section{Discussion}

The results of this study indicate that CSR has no effect on repurchase intention. The theoretical concept of Thi \& Le Van, (2016) cannot be proven in this study, because it states that companies in the consumer industry must develop marketing based on the social responsibility component to strengthen trademarks in consumer perceptions, and change consumers' minds to purchase interests. The results of this study do not support the results of previous studies conducted by Tsai et al., (2016), Saju Jose Nilesh Khare F. Robert Buchanan, (2015), and Bello et al., (2020) which state that CSR has a positive effect. and significant to repurchase intention. This happens because the objects in the previous research mentioned above do not only carry out philanthropic responsibility but there are several others such as legal responsibility, economic responsibility, and environmental responsibility, where the program is carried out in a sustainable manner and is used as a company marketing strategy so that the brand is attached to it. consumer memory that the company is responsible for other things around it. This is different from Chatime, which during the pandemic only focused on carrying out philanthropic responsibility by sharing its products with medical personnel, and inviting consumers to share Chatime products with online motorcycle taxi riders. Chatime did not really show the CSR activities carried out, but only a number of online news portals, and Chatime's own social media that uploaded information about the program. The CSR program carried out by Chatime during the

The Effect of Corporate Social Responsibility (CSR), Food Quality, and Perceived Value on Repurchase Intention Through Customer Satisfaction as Intervening Variables in The Pandemi Covid-19 Era (Study On "Chatime" Bubble Drink Products). 
pandemic also did not take place continuously, but only for a certain period, this made the program less likely to reach consumers 'memories, and made consumers' repurchase intentions of Chatime products not caused by CSR activities that were carried out. run. The majority of respondents in this study were 21-25 years old with an average expenditure of $<\mathrm{Rp} .1,000,000$ per month. This shows that the majority of respondents do not have high income so they do not have the ability to participate in the CSR program run by Chatime by inviting consumers to share with online motorcycle taxi drivers. In addition, the majority of respondents only knew about the Chatime sharing program without having any interest in participating in the program. Seeing the above, if Chatime targets its CSR program as a means of corporate marketing strategy, Chatime must develop a CSR program that is run into a sustainable program, or not only for certain periods. Chatime can also develop CSR programs that are not only in the philanthropic field but also in other fields such as the environmental sector which is adjusted to the characteristics of Chatime's target market, namely adolescents. According to Czap, (2010) in Kristando \& Indarwati, (2021) a group of young people or adolescents is a group with a low income level, where this group is more willing to carry out activities or activities in protecting the environment, rather than having to spend money to donate. Young consumers or teenagers will be happy to participate in a company's CSR program if the sacrifices made when buying a product include donating or participating in CSR programs run by the company, but it is different from the "Chatime Berbagi" program which invites consumers to increase product purchases. Chatime to share with online motorcycle taxi drivers, this makes consumers unwilling to join the program because they have to add sacrifices in the form of money. Chatime can make the CSR program run more attractive to consumers, and can lead to an increase in repeat purchase intentions if the program is implemented according to its target market, namely teenagers.

Next, the results of this study indicate that there is an effect of food quality on repurchase intention. These results are able to prove the theoretical concept of Kotler (2009: 235) which states that high repurchase intentions represent a high level of consumer satisfaction based on the perception that the desired product or service is of good quality. This study supports the results of previous research conducted by Muliawan (2018) which states that food quality has a positive influence on repurchase intention. Chatime has been able to improve and maintain the quality of its products based on its various dimensions. Research that states the same thing is that conducted by Faradiba \& Astuti (2013), Hermanto \& Cahyadi (2015), Harfania (2018), which states that there is a positive and significant effect on product quality (food) on Repurchase Intention. The results of this study indicate that consumers consider Chatime to be able to serve drinks with good or quality food quality, which makes consumers' repurchase intention to increase. In this study, Chatime, which has a superior product in the form of tea drinks with toppings on it, can be measured for quality using indicators of color and taste. This is because the color combinations in Chatime products are always interesting and different from one another and this is able to make consumers feel that these products are of good quality. Next on the taste indicator, Chatime with the characteristic of selling cold drinks is able to provide a fresh taste for consumers who consume its products, this indicates that the products offered by Chatime are of good quality. The results of the analysis show that overall respondents agree that Chatime is able to serve drinks with a fresh taste, this shows that Chatime always serves quality drinks. The majority of respondents in this study were women aged 21-25 years. Teens have a tendency to like to buy, or consume something based on a growing trend (cnnindonesia.com, 2018). Women who are the

The Effect of Corporate Social Responsibility (CSR), Food Quality, and Perceived Value on Repurchase Intention Through Customer Satisfaction as Intervening Variables in The Pandemi Covid-19 Era (Study On "Chatime" Bubble Drink Products). 
majority of respondents also support the results of this study, in which women have a high emotional side so it is very important for a woman to pay attention to the little things that will be consumed (Marsellita, Priska Viani \& Veranita Goenawan, 2008).

The results of this study indicate that perceived value has no effect on repurchase intention. This cannot prove the theoretical concept of Kotler (2009: 235) which states that high repurchase intentions represent a high level of satisfaction from consumers based on the perception that the desired product or service is of good quality. The results of this study do not support the results of previous studies by Pham et al., (2018), Tresna et al., (2019), Huang et al., (2019), Nhi et al., (2019), and Frendy (2013) which states that Perceived Value has a positive and significant effect on repurchase intention. Companies are required to be able to increase comfort and reduce non-monetary costs incurred by consumers such as time and energy which aim to increase the perceived value of the customer, which is in accordance with the results of the above research which states that if the perceived value increases, the consumer's intention to do repeat purchases will also increase.

The results of the analysis show that the majority of respondents feel that the sacrifices issued are not in accordance with the perceived products and services. The majority of respondents in this study were adolescents with professions as students or college students. Chatime carries the concept of a take away caffe, which makes consumers have to bring home products that have been purchased, or cannot consume them at the outlet where the purchase is made. Most of Chatime's outlets are located in malls and the size of the outlets is not too large, making Chatime employ not too many staff at each of its outlets. This makes buyers have to queue for quite a long time. The company's operational management system must be paid more attention, given the endless queues of Chatime buyers, and the relatively slow service process that makes consumers feel that the value received is not in accordance with the sacrifices made. Responding to the above, the company must think about other things that can provide added value to customers, the company must pay attention to the operational system in serving consumers so that it is in accordance with the sacrifices issued by consumers. Consumers will feel satisfied and have repeated purchase intentions if after the first purchase the consumer feels that the sacrifice incurred is proportional to the product received.

The results of this study indicate that CSR has no effect on customer satisfaction. This is able to prove the theory by Lupiyoadi (2001: 122) which states that there are 5 driving factors for customer satisfaction, and CSR is not one of them. This shows that the company's CSR programs cannot affect customer satisfaction. The results of this study do not support previous research conducted by Loureiro et al., (2012), Chung et al., (2015), and by Nareeman \& Hassan, (2013) showing that CSR in the environmental sector has the highest impact on satisfaction. consumer. This is different from what happened in this study which used philanthropy responsibility as an indicator to measure the CSR variable, which was adjusted to the CSR program carried out by the object of research, namely Chatime. In this research, Chatime runs a CSR program by distributing its products to people affected by the Covid-19 pandemic, and inviting the public to share Chatime products with online motorcycle taxi riders. This is of course not directly related to Chatime products consumed by consumers, so that the CSR program cannot increase consumer satisfaction. The majority of respondents in this study were aged 21-25 years, at which age the respondents were less interested in joining a program that had to spend a certain amount of money (Czap, 2010) (Kristando \& Indarwati, 2021). Respondents in this study considered that their level of

The Effect of Corporate Social Responsibility (CSR), Food Quality, and Perceived Value on Repurchase Intention Through Customer Satisfaction as Intervening Variables in The Pandemi Covid-19 Era (Study On "Chatime" Bubble Drink Products). 
satisfaction with Chatime was not influenced by the CSR program being implemented, but rather on the products and services that Chatime provided to consumers.

The results of this study indicate that food quality has an effect on customer satisfaction. This is able to prove the theory by Lupiyoadi $(2001: 122)$ that there are 5 factors driving customer satisfaction, and product quality is one of the factors driving customer satisfaction. In this study, consumers were satisfied with the food quality of the products served by Chatime. This study also supports the results of previous studies by Berliansyah \& Suroso (2018), Ha \& Jang (2010), Weliani (2017), and Muliawan \& M (2018) which stated that food quality has an effect on customer satisfaction. Hidayat et al., (2020) stated that company management must be able to provide innovation in the beverage product variants offered, and increase the portion size of food served. This is an effort made to maintain consumer satisfaction with food quality. The results of research by Hidayat et al., (2020) are in accordance with what Chatime did in this study. Chatime currently has more than 40 menu variants that are always increasing, and innovating according to consumer tastes and needs. The results of the analysis show that overall respondents feel that they agree with the expression that the taste of a drink can affect the quality of the drink. This is because taste is the main thing that influences consumer perceptions of the quality of a drink which in turn can provide consumer satisfaction with Chatime products that have been consumed.

The results of this study indicate that perceived value has an effect on customer satisfaction. This proves the theory by Lupiyoadi (2001: 122) that there are 5 factors driving customer satisfaction, one of which is emotion. Emotional factors are factors that contain things that consumers feel about the products they consume or the companies that make them. The results of this study support the results of previous studies conducted by Abdul Raji, Mohd Nazri et al., (2016), and Frendy (2013) which state that there is a positive and significant relationship between perceived value and customer satisfaction. This shows that Chatime consumers feel the value obtained from consuming Chatime products can encourage consumer satisfaction. Chatime is considered capable of providing a good emotion to consumers when consumers have consumed the product, thus leading to consumer satisfaction. Overall respondents agree that the products and services provided by Chatime are worth buying even during the Covid-19 pandemic. This shows that Chatime is able to maintain the quality of products and services that can provide value to the minds of consumers even during the Covid-19 pandemic. Chatime has succeeded in maintaining the value felt by consumers so that it is able to encourage consumer satisfaction with the products and services provided. Chatime must be able to maintain and improve this, considering that during the pandemic, business competition is getting tighter and more difficult, so only products that can be consistent can survive.

Then the results show that customer satisfaction has an effect on repurchase intention. The results of this study are able to prove Kotler's (2009: 235) theory states that high repurchase intentions represent a high level of satisfaction from consumers based on the perception that the desired product or service is of good quality. The results of this study support the results of previous research by Berliansyah \& Suroso, (2018), Hidayat et al., (2020), Weliani (2017), Leonnard (2018), and Frendy (2013) which explain to increase consumer repurchase intention, management. the upper level must pay attention to consumer satisfaction, this can be realized by improving the quality of food and beverages, as well as considering appropriate prices for the products offered. Respondents of this study felt that Chatime as a producer of contemporary drinks was able to serve products that were in accordance with consumer expectations, and was able to meet their needs. Consumers who feel their

The Effect of Corporate Social Responsibility (CSR), Food Quality, and Perceived Value on Repurchase Intention Through Customer Satisfaction as Intervening Variables in The Pandemi Covid-19 Era (Study On "Chatime" Bubble Drink Products). 
needs are met will be satisfied with the products and services received from these producers. Customers of Chatime products are satisfied and have a higher intention to buy back Chatime products in the future. The results of the analysis show that overall respondents agree that they are always satisfied with Chatime's bubble drink products and services even during the Covid-19 pandemic. This shows that the performance of Chatime's products and services has not changed even during the pandemic, which is able to make consumers feel satisfied. In this study, the respondents used were Chatime consumers who had purchased Chatime products in the last three months (since November 2020) and some of the respondents had made purchases more than once during that time. This shows that Chatime consumers are satisfied with the products and services provided by Chatime, so they always make repeat purchases.

\section{CONCLUSION}

Based on the data and discussion above, it can be concluded that CSR has no effect on repurchase intention or on customer satisfaction. The food quality variable in this study has an effect on repurchase intention, as well as on the customer satisfaction variable. The variable perceived value in this study has an effect on customer satisfaction, but has no effect on the repurchase intention variable. Next, the customer satisfaction variable has an effect on repurchase intention. The role of customer satisfaction $(Z)$ as a mediating variable in this study is able to mediate the relationship between the food quality variable on repurchase intention, as well as the variable perceived value on repurchase intention. The results differ on the relationship between the CSR variable on repurchase intention which cannot be proven by the influence of the mediating variable on this relationship.

The CSR variable in this study has no effect on repurchase intention and customer satisfaction. Seeing the above, Chatime must develop a CSR program that is run into a sustainable program, or not only for certain periods. Chatime can also develop CSR programs that are not only in the philanthropic field but also in other fields such as the environmental sector which is adjusted to the characteristics of Chatime's target market, namely adolescents. However, Chatime was able to keep the quality of the products it sold at its prime during the pandemic. Food quality is one of the driving factors for customer satisfaction that companies must pay attention to, in this case Chatime has implemented it well. Next, the value felt by Chatime's customers is only able to encourage customer satisfaction, this is because of the quality of the products consumed. Chatime consumers think that what is received is not worth the sacrifices spent to get Chatime products. Companies need to pay attention to consumer convenience when queuing when buying, as well as evaluate the company's operational management system so that consumers don't queue too long. This is in accordance with the opinion of Kotler (2009: 235) which states that high repurchase intentions describe a high level of satisfaction from consumers based on the perception that the desired product or service is of good quality.

The problem in this study is to find respondents in each area where Chatime outlets are located, there are several provinces where Chatime outlets are located in Indonesia that are not accessible to researchers so that there are no respondents who come from these areas, for the next researchers are expected to be able to reach all areas where Chatime outlets established in Indonesia are needed to support research.

The Effect of Corporate Social Responsibility (CSR), Food Quality, and Perceived Value on Repurchase Intention Through Customer Satisfaction as Intervening Variables in The Pandemi Covid-19 Era (Study On "Chatime" Bubble Drink Products). 


\section{REFERENCES}

Arief, A. M. (2020, August 5). Kuartal III/2020, Sektor Makanan \& Minuman Jadi Penggerak Utama Industri Pengolahan. Bisnis.com;bisnis.com. https://ekonomi.bisnis.com/ read/20200805/257/1275601/kuartal-iii2020-sektor-makanan-minuman-jadi-penggerakutama-industri-pengolahan (accessed on16 November 2020)

Akmalul Azmi. (2020, May 27). Chatime Berbagi 100 Ribu Cup Minuman di Tengah Pandemi Covid-19. TIMES Indonesia; TIMESIndonesia. https://www.timesindonesia.co.id/read/ news/273926/chatime-berbagi-100-ribu-cup-minuman-di-tengah-pandemi-covid19 (accessed on16 November 2020)

Bagaimana Penilaian Bagi Merek Dalam Survei Top Brand? | Top Brand Award. (2019, August 14). Top Brand Award.https://www.topbrand-award.com/en/2019/08/bagaimanapenilaian-bagi-merek-dalam-survei-top-brand-2/ (accessed on16 November 2020)

Bahar, A., \& Sjahruddin, H. (2017). Pengaruh Kualitas Produk Dan Kualitas Pelayanan Terhadap Kepuasan Konsumen Dan Minat Beli Ulang. 3, 14-34. https://doi.org/10.31227/ osf.io/tc2fe

Basoni, S. (2018, October 10). Populer di Berbagai Negara, Bubble Tea Disebut Sebagai Minuman Tidak Sehat. Detikfood; detikcom. https://food.detik.com/info-sehat/d-4250327/ populer-di-berbagai-negara-bubble-tea-disebut-sebagai-minuman--tidak-sehat

Bello, K. B., Jusoh, A., \& Md Nor, K. (2020). Relationships and impacts of perceived CSR, service quality, customer satisfaction and consumer rights awareness. Social Responsibility Journal, May. https://doi.org/10.1108/SRJ-01-2020-0010

BERLIANSYAH, R. A., \& SUROSO, A. (2018). The Influence of Food \& Beverage Quality, Service Quality, Place, and Perceived Price to Customer Satisfaction and Repurchase Intention. Journal of Research in Management, 1(1), 28-37. https://doi.org/10.32424/ jorim.v1i1.18

Chatime Melalui CSR Kawan Lama Sebarkan Kebahagiaan di Tengah Pandemi. (2020, May 27). Harian Bhirawa Online. https://www.harianbhirawa.co.id/chatime-melalui-csrkawan-lama-sebarkan-kebahagiaan-di-tengah-pandemi/

Chung, K.-H., Yu, J.-E., Choi, M.-G., \& Shin, J.-I. (2015). The Effects of CSR on Customer Satisfaction and Loyalty in China: The Moderating Role of Corporate Image. Journal of Economics, Business and Management, 3(5), 542-547. https://doi.org/10.7763/ joebm.2015.v3.243

CNNIndonesia. (2018, April 19). Alasan Generasi Milenial Lebih Konsumtif. Gaya Hidup; cnnindonesia.com. https://www.cnnindonesia.com/gaya-hidup/20180418215055-282291845/alasan-generasi-milenial-lebih-konsumtif

Faradiba, \& Astuti, S. R. T. (2013). Analisis Pengaruh Kualitas Produk, Harga, Lokasi, Dan Kualitas Pelayanan Terhadap Minat Beli Ulang Konsumen (Studi pada Warung Makan "Bebek Gendut" Semarang). Diponegoro Journal of Management, 2(3), 1-11.

Ha, J., \& Jang, S. C. (Shawn). (2010). Effects of service quality and food quality: The moderating role of atmospherics in an ethnic restaurant segment. International Journal of Hospitality Management, 29(3), 520-529. https://doi.org/10.1016/j.ijhm.2009.12.005

Harfania, F. (2018). Pengaruh Promosi Penjualan , Experiential Marketing, Kualitas Produk Dan Kualitas Pelayanan Terhadap Minat Beli Ulang ( Studi Kasus Pada Restoran Ayam Geprek Sa 'I Yogyakarta ). Jurnal Fakultas Ekonomi, 3, 581-591.

Hermanto, K., \& Cahyadi, I. (2015). Pengaruh Kualitas Produk Dan Harga Terhadap Minat Beli Ulang Fast Food Ayam Goreng Tepung Di Kalangan Mahasiswa Universitas Kristen Petra Surabaya. Jurnal Hospitaly Dan Manajemen Jasa, 3, 361-387.

Huang, L. C., Gao, M., \& Hsu, P. F. (2019). A study on the effect of brand image on perceived value and repurchase intention in ecotourism industry. Ekoloji, 28(107), 283-287.

Kronologi Munculnya Covid-19 di Indonesia hingga Terbit Keppres Darurat Kesehatan Halaman 4 | merdeka.com. (2020, April 2). Merdeka.com. https://www.merdeka.com/trending/ kronologi-munculnya-covid-19-di-indonesia-hingga-terbit-keppres-darurat-kesehatankln.html?page $=4$ (diakses pada 15 November 2020)

The Effect of Corporate Social Responsibility (CSR), Food Quality, and Perceived Value on Repurchase Intention Through Customer Satisfaction as Intervening Variables in The Pandemi Covid-19 Era (Study On "Chatime" Bubble Drink Products). 
Leonnard. (2018). Perceived Service Quality, Perceived Value for Money, Satisfaction and Repurchase Intention : an Evaluation on Private University Services. International Journal of Commerce and Finance, 4(1), 40-51.

Liputan6.com. (2020, June 30). Sri Mulyani: Corona Beri 3 Dampak Besar ke Ekonomi Indonesia. Liputan6.com; Liputan6. https://www.liputan6.com/bisnis/read/4292763/srimulyani-corona-beri-3-dampak-besar-ke-ekonomi-indonesia (diakses pada 15 November 2020)

Loureiro, S. M. C., Dias Sardinha, I. M., \& Reijnders, L. (2012). The effect of corporate social responsibility on consumer satisfaction and perceived value: The case of the automobile industry sector in Portugal. Journal of Cleaner Production, 37, 172-178. https:// doi.org/10.1016/j.jclepro.2012.07.003

Lupiyoadi, R. (2001). Manajemen Pemasaran Jasa: Teori dan praktik. . Jakarta: PT. Salemba Emban Patria. 122

Maholtra, N. (2009). Riset Pemasaran. Jakarta: PT Index.

Margaretha Fiani S. dan Edwin Japarianto, S.E., M. M. (2012). ANALISA PENGARUH FOOD QUALITY DAN BRAND IMAGE TERHADAP KEPUTUSAN PEMBELIAN ROTI KECIK TOKO ROTI GANEP'S DI KOTA SOLO. Physical Review B, 47(1), 334 -341. https://doi.org/10.1103/PhysRevB.47.334

Marsellita, Priska Viani, \& Varenita Goenawan. (2008). ANALISA PERBANDINGAN HARAPAN DAN PERSEPSI PRIA DAN WANITA DALAM MEMILIH SEBUAH RESTORAN DI SURABAYA DITINJAU DARI SEGI MEAL EXPERIENCE. Jurnal Perhotelan Petra. http://webcache.googleusercontent.com/search? q=cache:N1Fk4YgeF88J:jurnalperhotelan.petra.ac.id/index.php/hot/article/ view $/ 18419 / 18236+\& \mathrm{~cd}=2 \& \mathrm{hl}=$ en $\& \mathrm{ct}=\mathrm{clnk} \& \mathrm{gl}=\mathrm{id}$

Muliawan, S., \& M, D. S. S. M. . (2018). Pengaruh Food Quality dan Ketersediaan Produk Terhadap Repurchase Intention Produk Sari Roti di Surabaya. Jurnal Strategi Pemasaran, 5(2), 1-6. $\quad$ http://publication.petra.ac.id/index.php/manajemen-pemasaran/article/ view/7047

Nancy, C. S., Varel, J. C., \& Hanjaya, S. (2020). Pengaruh Kualitas Makanan, Higienitas Dan Kualitas Layanan Terhadap Minat Pembelian Ulang Melalui Kepuasan Konsumen Sebagai Mediator Di Restoran Dapur Terbuka Di Surabaya. 67-76.

Nareeman, A., \& Hassan, Z. (2013). Customer Perceived Practices of CSR on improving customer satisfaction and loyalty. International Journal of Accounting and Business Management, $\quad 1(1), \quad 30-49 . \quad$ https://www.researchgate.net/ publica-

tion/316014348 Customer Perceived Practices of CSR on improving customer satisf action and loyalty

Palupi Annisa Auliani. (2020, August 6). Pertumbuhan Ekonomi Minus 5,32 Persen: Sekali Lagi, Tolong Kendalikan Pandeminya Halaman all - Kompas.com. KOMPAS.com; Kompas.com. https://money.kompas.com/read/2020/08/06/122846926/pertumbuhanekonomi-minus-532-persen-sekali-lagi-tolong-kendalikan-pandeminya?page=all (diakses pada 16 November 2020)

Pham, Q. T., Tran, X. P., Misra, S., Maskeliunas, R., \& Damaševičius, R. (2018). Relationship between convenience, perceived value, and repurchase intention in online shopping in Vietnam. Sustainability (Switzerland), 10(1). https://doi.org/10.3390/su10010156

Pérez, A., \& del Bosque, I. R. (2015). Corporate social responsibility and customer loyalty: Exploring the role of identification, Satisfaction and type of company. Journal of Services Marketing, 29(1), 15-24. https://doi.org/10.1108/JSM-10-2013-0272

Saju Jose Nilesh Khare F. Robert Buchanan. (2015). International Journal of Bank Marketing. International Journal of Bank Marketing, 12(7), 1-32. https:// doi.org/10.1108/02652323199400002

Thi, Q., \& Le Van, P. (2016). Consumers' perception towards Corporate social responsibility and repurchase intention: A study of consumer industry in Vietnam. Industrial Engineering and Management Systems, 15(2), 173-180. https://doi.org/10.7232/

The Effect of Corporate Social Responsibility (CSR), Food Quality, and Perceived Value on Repurchase Intention Through Customer Satisfaction as Intervening Variables in The Pandemi Covid-19 Era (Study On "Chatime" Bubble Drink Products). 
iems.2016.15.2.173

Tresna, P. W., Suryanto, \& Haidysirly, H. (2019). Effect of perceived value on repurchase intention in e-commerce: A study on the Female Daily mobile application. International Journal of Trade and Global Markets, 12(3-4), 373-380. https://doi.org/10.1504/ IJTGM.2019.101560

Tsai, H. T., Chang, H. C., \& Tsai, M. T. (2016). Predicting repurchase intention for online clothing brands in Taiwan: quality disconfirmation, satisfaction, and corporate social responsibility. Electronic Commerce Research, 16(3), 375-399. https://doi.org/10.1007/ s10660-015-9207-2

Tjiptono, F. (2012). Strategi Pemasaran. Yogyakarta: Andy.

Weliani, S. (2017). Analisa Pengaruh Food Quality, Service Person Customer Orientation, Dan Physical Environment, Terhadap Repurchase Intention, Melalui Customer Satisfaction. ULTIMA Management, 7(1), 39-61. https://doi.org/10.31937/manajemen.v7i1.923 